\title{
Mycosis Fungoides and Sezary Syndrome M1 TNM Finding v7
}

National Cancer Institute

\section{Source}

National Cancer Institute. Mycosis Fungoides and Sezary Syndrome M1 TNM Finding v7. NCI Thesaurus. Code C88248.

Visceral involvement (must have pathology confirmation and org an involved should be specified). Note: for viscera, spleen and liver may be diagnosed by imaging criteria. (from AJCC 7th Ed.) 